\title{
Political economy and citizen empowerment: Strategies and challenges of Emiratisation in the United Arab Emirates
}

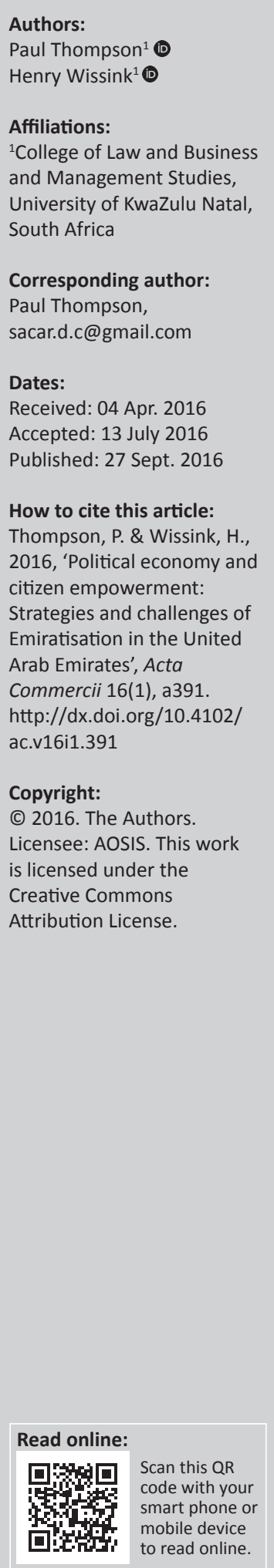

Orientation: The United Arab Emirates' labour market by design is inclined to exclude generally the Emirati population from active participation in the private sector, in order to take advantage of cheap labour primarily from South Asia.

Research purpose: The aim of this article was to explain, using labour market segmentation theory, how the present epoch of free market capitalism in the 'minority state' of the United Arab Emirates (UAE) has socially excluded its' citizens.

Motivation for the study: The pro-national Emiratisation or employment policy project implemented by the federal government in 1998 provided an opportunity for UAE citizens to be fully absorbed in the private and public sectors. Researching the process as it unfolded, insights are unearthed as to why Emirati citizens are still on the periphery of the country's labour market.

Research design, approach and method: The article employed a qualitative methodology using the UAE as a single case study.

Main findings: The research on the UAE's Emiratisation or labour nationalisation policies found that there are a number of systemic and structural barriers that have hampered the successful implementation of government policies in both the private and public sectors.

Practical/managerial implications: Policy makers need to be able to differentiate between the systemic, structural and institutional factors that have stymied government's attempt at addressing the country's demographic imbalance and the social exclusion of Emirati citizens from the labour market.

Contribution/value-add: This research has filled a gap in literature on the theme, and has also deviated from earlier research findings on the barriers to achieving policy targets.

\section{Introduction}

The post-Britannica period in the Arabian Peninsula state of the United Arab Emirates (UAE) has evolved into an ethnically pluralistic society. This pluralism has symbolically and systemically impacted disproportionately on the integration of Emirati citizens within the social and economic units of the country's private sector. Researchers such as Kawach (2010) and Forstenlechner and Rutledge (2012) have noted that the 'southern Arabian Gulf states including the UAE are faced with a growing phenomenon of demographic imbalance in its population structures'. The raison d'être for the noted '... demographic shift in the structure of the UAE's population is due in part to the rapid socio-economic transformation of the economy over the last four decades' (Kanna 2010:103-104; Shihab 2001:251). In addition, the economically active segment of the Emirati population is comparably small in relation to the total labour market demand of the economy.

The epistemic perspective of Emiratisation or labour market nationalisation provides an example of what Mashood, Verhoeven and Chansarkar (2009:2-3) refer to as a labour market 'interventionist approach often undertaken by governments of the region'. The process of labour market intervention (Emiratisation) in the UAE as a federal policy owes its genealogical roots to significant demographic changes in its population structure. Such changes have been 'initially fuelled by the oil industry that has created a constant demand for foreign workers from both core and peripheral countries to fill jobs that locals are not qualified to perform; and also to perform jobs they (Emiratis) do not want to perform' (Alzaabi 2012:IV; Pacione 2005:255). This article advances the argument that socio-economic expansion and Emiratisation in the UAE are interrelated, notwithstanding 
that the process is inherently hampered by fundamental structural problems and policy contradictions.

Structurally, the thematic issues of the article begin with the section on the 'Theoretical framework', which situates the study within labour market segmentation theory. Localisation and demographical imbalance are dealt with in the next section. The section thereafter provides insight into the political economy of Emiratisation policies in the UAE. The codification and legalisation of the Emiratisation framework are then discussed. A synopsis of the core tenets of the Emiratisation policies is provided in the following section. Finally, the section titled 'Systemic barriers and challenges' contextualises a number of constraints, challenges and critiques faced by the state in the implementation of the federal policy of labour nationalisation.

\section{Methodology}

The primary overarching objective of this article is to provide a descriptive account of the political, socio-economic and cultural systemic constraints to the successful implementation of the UAE's Emiratisation policies. To achieve this objective, a theoretical framework based on segmentation of the labour market theory was embraced. Given the nature of the prescribed theoretical framework, this article employs a qualitative methodology using a single case study and descriptive research approach. The descriptive approach is deemed an appropriate choice for this article, as it 'is used when the purpose of research is the accurate description of a situation or an association between variables' (Kothari 2006:33). Data on the UAE's population demographic imbalance and labour nationalisation policies were gathered from various sources but primarily from document analysis and direct observation. In this study, document analysis is an integral part of the qualitative mode of inquiry, as it is used to map historical information on the UAE's government's initiatives on labour market localisation and some of the systemic constraints encountered. The study reviews key documents, including statistical reports from both federal and local governments; newspaper articles; the Dubai Strategic Plans of 1996, 2010 and 2015; academic papers; and other relevant documents.

\section{Theoretical framework: Theory of labour market segmentation}

The orthodoxy of labour market segmentation is used in this article to contextualise the substantive and symbolic process of Emiratisation. The 'labour market segmentation theory explains the economic marginalization of ethnic minorities, lower classes and women' (Clairmont et al. 1983; Fevre 1992 cited in Bauder 2001:37). Segmentation, taken literally, is of significance when it results in the failure of the labour market to treat its participants even-handedly and accords significantly different opportunities and rewards to otherwise comparable people (Ryan 2013:3-4 in Wilkinson 2013:3-4). Labour market segmentation in the UAE is an outgrowth of racial capitalism that subjugates and degrades nationalities from the so-called core Western countries. This article makes use of the following definition of 'labour market segmentation':

...the historical process whereby political and economic forces
encourage the division of the labour market, into separate sub-
markets, or segments, distinguished by different labour market
characteristics and behavioural rules. Segmented labour markets
are thus the outcome of a segmentation process in which
segments may cut horizontally across the occupational hierarchy
as well as vertically. (Reich, Gordon \& Edwards 1973:359)

The labour market of the UAE may be characterised as being two-tiered and bifurcated, comprised of expatriates and their subsets of various nationalities and occupational groups on the one hand and the indigenous population segment of the labour market on the other. However, these two primary tiers are governed by different sets of regulations. For example, according to the Labour Law of 1980, the mobility of expatriate labour is legally limited by the kafala (sponsorship) system, in which private sector employers rigidly control the movement of employees under their sponsorship in the country.

Similarly, mobility within the Emirati segment of the labour market is restricted by 'an unwritten rule that the public sector is responsible for securing job opportunities for all national workers' (Girgis 2002; Hertog 2010). This paradoxically and invariably places Emiratis into selfimposed exclusion from certain occupational categories in the private sector. Girgis also notes that:

\begin{abstract}
...duality in the GCC [Gulf Cooperating Council] and the UAE in particular takes different forms. To illustrate, a dual labour market is established when government policies ensure that clear preferences are made for hiring nationals with limited quotas imposed on hiring/retaining expatriates. Generally in the GCC, a dual labour market situation emerged over time and reflected each nation's attempt to deal with labor scarcities and national priorities during a period of rapid growth. (2002:28)
\end{abstract}

The stratification of the UAE labour market has become socially, culturally and economically polarising owing to the plurality of nationalities with their various socio-cultural and political inclinations. The developmental agenda as contained in the Dubai Strategic Plans 2000 and 2015 and UAE's Vision 2021, coupled with the UAE's free market economy model, will continue to have serious ramifications for the demographic composition of the labour market. An analysis of those development strategic plans reveals that the overarching developmental goal of the country does not lend itself to the homogenisation of the labour market. Instead, it leads to a market that will continue to be segmented on the basis of nationality, salary scale, ethnicity and occupation. Segmentation of the UAE's labour market is demonstrative of a social order that is premised on a socio-economic system that is the embodiment of 'core-periphery relation' (Matthiesen 2015:321). This is due in part to the fact that the UAE has become a quintessential player in the globalisation of human capital. Against that background, labour market segmentation theory is appropriate in situating the duality and the ethnic hierarchical configuration of the UAE labour 
market when compared to other theories such as human capital theory. In explaining human capital theory, Ehrenberg and Smith (1997) describe '...workers as embodying a set of skills which can be "rented out" to employers. The knowledge and skills a worker has generates a certain stock of capital'.

\section{Need for localisation and demographical imbalance}

Al-Ali (2008); Rees, Mamman and Braik (2007); Goodwin (2006); and Al-Waqfi and Forstenlechner (2010) have highlighted '...the importance of Emiratisation as a policy directive needed to address the demographical imbalance that currently prevails in the UAE'. This article employs the notion that the historicity of the changing demographic structure of the UAE or an ethnically pluralistic society '... can be traced back to the country's colonial encounter in the sixteenth century. Subsequent to that initial encounter waves of international migration have not abated in the GCC and the UAE in particular' (El-Sanabary 1992:5; Ramos 2008:1).

The historical mapping of the entry of foreign guest workers into the UAE primarily started subsequent to the discovery of oil in the 1950s and 1960s, respectively. For example, AlAwadh (2007) noted that the '...official census of 1968 showed at that time $37 \%$ of the gross population was made up of immigrants, which affected the structure of the demographic pyramid, as most of them were economically active males'. Table 1 shows actual and estimated figures in the pattern of demographic changes in the UAE population structure it also depicts the population growth and structure between 1975 and 2013, with UAE nationals recording a net population increase of approximately 6.9 times (from $0.202 \mathrm{~m}$ to $1.4 \mathrm{~m}$ ) and non-nationals showing a 21 -fold increase ( 0.36 million to 7.8 million). Meta-analysis of the statistics outlined in Table 1 suggests that the UAE suffers from a protracted demographic imbalance between UAE nationals and non-nationals. Such demographic imbalance or multiplicity of nationalities makes the UAE 'one of the most ethnically diverse nation states globally' (Global Compact International Yearbook 2009:61). The uniqueness of the UAE's population structure and labour market conundrum is explained by Birks and Sinclair (1980:72), who noted '...the UAE is perhaps the best

\begin{tabular}{lccc}
\multicolumn{4}{l}{ TABLE 1: Demographic changes in the UAE's population. } \\
\hline Years & $\begin{array}{c}\text { Emirati } \\
\text { population }\end{array}$ & $\begin{array}{c}\text { Expatriate } \\
\text { population }\end{array}$ & $\begin{array}{c}\text { Total } \\
\text { population }\end{array}$ \\
\hline 1975 & 202000 & 356000 & 558000 \\
1980 & 291000 & 751000 & 1042 million \\
1985 & 396000 & 983000 & 1379 million \\
1995 & 587000 & 1824000 & 2411 million \\
2004 & 906000 & 3414000 & 4320 million \\
2005 & N/A $\dagger$ & N/A & 4100000 \\
2008 & 892000 & 3.873 million & 4.76 million \\
2009 & 923000 & 4.143 million & 5.06 million \\
2010 & 1074329 & 7189741 & 8264070 \\
2013 & 1.4 million & 7.8 million & 9.2 million \\
\hline
\end{tabular}

Source: Al-Ali 2008; UAE Yearbook 2010, 2014

UAE, United Arab Emirates.

$\dagger$, Disaggregated population figure was not available for the Emirati population of the UAE.

$\ddagger$ Disaggregated population figure was not available for the expatriate population in the UAE. example of a capital-rich state suffering from severely limited indigenous human resources'. Al-Ali (2008:01) amplifies this point in stating that 'Emiratis are a minority in their own country, comprising two of every ten in the population'.

The necessity for the nationalisation of the UAE's labour market is further demonstrated here. For example, in 2002 'UAE nationals contribute[d] only $8 \%$ of employees in the public sector and $1 \%$ in the private sector, yet they [had] a comparatively high unemployment rate' (Al-Ali 2008:01). The Emiratisation or labour nationalisation programme by the government is not simply 'an affirmative action policy that aims to give preferential hiring status to its citizens but it is also an attempt of preserving national identity' (Modaress, Ansari \& Lockwood 2013: Abstract). In recent years, there has been a concern among policymakers and citizens in the UAE that '.. in the face of globalisation, there is an ominous prospect of the disappearance of the local culture and national identity' (Khondker 2008:08). The cultural pluralism of the society and 'the nature of labour market segmentation in GCC countries including the UAE, have contributed to the perceived erosion of cultural and national identity' (Bauder 2001:37). Within that context, Emiratisation takes on a multiplicity of imperatives and necessities, in addition to the quantitative targets stipulated in the policy directives.

\section{Political economy of Emiratisation in the UAE}

The political economy of the GCC nation states and the UAE in particular:

... [is] facing political challenges that traditional patrimonialism may not be able to withstand, as a result of their extra-ordinary socio-economic development over the last 30 years. Explosive economic growth is now generating unrest from citizens felt bypassed by economic growth and the indigenous populations that have been dwarfed by expatriate communities. (Hudson 2009:45)

The concept of '...political economy in its current usage is a term that encompasses a wide variety of approaches to studying the relationship between what is called "the economy" and its "non-economic" (for example, political, socio-cultural, psychological and geographical) context' (Mosedale 2011:3). The political economy of Emiratisation policies within the UAE is framed and constricted within a 'broader socio-cultural, economic and political structure' (Hudson 2009:51). Emiratisation policies as implemented by the federal government are constitutively not just about equalising economic opportunities for locals in the period of equalising times, as is being suggested in discourses by scholars such as Davidson (2008), Al-Ali (2008) and Rees et al. (2007). It is essentially about reshaping the political economy of the country. The nationalisation of the labour force, according to Dupper and Sankaran (2014:143), 'is driven by political and economic imperatives, and both are inextricably interlinked in a labour market that is segmented and racially stratified'.

At a political level, Emiratisation as a 'canon of thought has become a metaphor' (Grosfoguel 2009; Mignolo 2000:7) 
and policy direction; for the state to use its legitimate power to reconstitute the present patron-client relationship, which is explained below. Such relationships are deeply entrenched within the psyche of Arab societies and the UAE is no exception. MacQueen (2013:181) explains that 'one way of understanding the patron-client relationships in the UAE is through the concepts of clientelism and patronage'. The indigenisation policies represent an epistemological shift in which the UAE's government has demonstrated '...subjectivity and timidity in dealing head on with the scenario in which individuals or groups act as clients by establishing relationships with the state as their patron to extract specific favours, whether it be employment, favourable treatment in terms of the judiciary or business' (MacQueen 2013:181; NdlovuGatsheni 2013:78).

The UAE is one of the signatories to the United Nations Convention on the Protection of the Rights of All Migrant Workers and Members of Their Families as well as the World Trade Organization's General Agreement on Trade Services. Notwithstanding, Mattar (2009:252) argues that '...Gulf States, including the UAE, view these two agreements as instruments forcing the naturalisation of its migrant labour forces. If this were to happen, naturalised migrant workers would dominate the society and eventually erase their Arab identity and gradual subordination of these societies'. Alzaabi (2012:23) has also echoed the view that 'if increased expatriate legal rights and privileges are accorded in the UAE, [...] over time they (legal rights) will exceed those of UAE nationals. Over time the host nationals (and their voices) will be marginalised. This will threaten the stability of the nation by the loss of its own identity'. The impetus and legitimacy of these concerns are based on the socio-economic reality in which:

...Emiratis hold about 15,000 jobs in the private sector. Given the shrinking percentage of citizens in the total workforce of the country, it is estimated that they may account for less than 4 per cent of the total workforce in 2020. (UAE Yearbook 2010:163)

Politically these two international agreements and the high percentage of migrant workers in the UAE 'worry government officials given the authoritarian nature of the political structure. Accordingly, the government have used instruments of the state to minimise the perceived threat' (Gamburd 2010:13) through legislations, decrees and ministerial resolutions. The UAE's Emiratisation policy is also an attempt by the state to address the peripherisation and constraints (discussed later) that prevent Emiratis from taking advantage of the opportunities generated by rapid economic growth in the UAE.

\section{Codifying and legalising the Emiratisation framework}

Sorenson notes that '...since the 1970s, but particularly with the end of the "bonanza oil decade" in the 1980s, the demographic challenge has become the most acute socioeconomic problem for an increasing number of Middle East countries' (2010:67). It is within this context that the government of the UAE has, under the aegis of economic development and social inclusion of its indigenous population, instituted a labour nationalisation programme for the socio-economic empowerment of its citizens. The UAE's affirmative action policies are fundamentally different from those in other countries such as South Africa or the USA in one respect. It is the politically dominant group, which is also an ethnic minority group that is implementing preferential policies to protect itself from an expatriate majority entrepreneurial class. Table 2 chronicles the historicity of the UAE's initiatives, legislation and decrees aimed at the nationalisation of the domestic labour market, which began in 1972 and continues to the present. These typologies of labour market initiatives indexed the path by which Emiratis can be integrated into the domestic labour market and simultaneously break the monopolistic hold that expatriates have on the domestic labour market in terms of the expatriate-to-Emirati ratio.

Apart from seeking to integrate Emiratis into domestic labour market, and correcting the incongruity that exists in the domestic labour market. The present raft of labour market policies and initiatives will to a certain extent; facilitate the decoupling of Emiratis from the public sector and simultaneously force private sector employers to absorb a larger percentage of the Emirati population into the

TABLE 2: Chronology of labour market reform initiatives in the UAE.

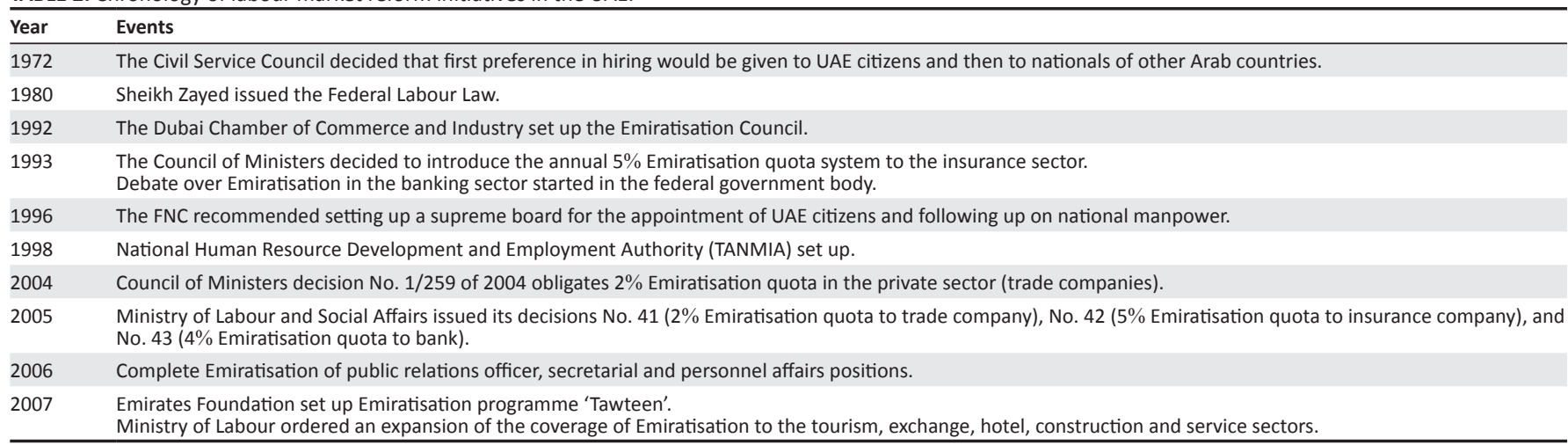

Source: al Abed, Vine \& al-Jabali 1996; Davidson 2005; Koji 2011

TANMIA, National Human Resource Development and Employment Authority; FNC, The Federal National Council. 
private sector. The creation of an effective regulatory environment of the UAE's labour market is fundamental to the continued economic empowerment of the country's citizens.

\section{Synopsis of Emiratisation policies}

The designs of the Emiratisation project represent the metonym of human resources development and sociocultural empowerment within non-state-owned institutions in the UAE. The Emiratisation policies outlined earlier are essentially about labour market reform. The policies were instituted in 1998 under the auspices of the National Human Resources Development and Employment Authority (TANMIA) and '...impose employment quotas on the banking, insurance and trade sectors' (Davidson 2005:176; Goodwin 2006). The targeted sectors identified above were selected based on '...two principal criteria: the first being, the economic health of the industry and its importance to the country and the second, the availability of skilled jobs, where good working conditions exist for nationals' (Ministry of Foreign Trade 2010). It is significant to note that quotas of Emirati employees are not allocated by the state bureaucracy but instead the process is self-administered internally by private sector companies.

The Council of Ministers' Resolution No. 10 for 1998, Article 1, requires that '... all banks operating in the UAE shall undertake to employ nationals (Emiratis) at an annual rate of $4 \%$, pursuant to the aforementioned resolution' (UAE Yearbook 2013:161). The 1998 resolution stipulates, for example, 'that $60 \%$ of bank employees should by 2013 be Emiratis. However, by the end of 2010 the average rate of Emiratisation in the banking sector was just 35.4\%' (UAE Yearbook 2013:161). At a micro-level the banking sector was targeted because of the opportunities it has to offer to nationals at a professional level, which feeds directly into the mudir syndrome that besets the local population.

The UAE is a quintessential trading nation, as evidenced by the fact that 'Dubai has emerged rapidly as a major entrêpot city' (Kapoor 2002:159). It is on that premise inter alia that the government sees the trading sector as key to the national economy in terms of the following:

Contribution to the national GDP [gross domestic product]. Analysis of the national macro-economic variables reveal, for example, that this sector contributes '...14.7\% to the GDP in 2010, $23 \%$ in 2011 and 21\% in 2012'. (UAE Yearbook 2013:61)

\section{The potential of the sector to employ Emiratis}

This has provided the impetus for the '...Council of Ministers to issue resolution No. 259/1 for 2004, obligating all trading firms employing 50 or more workers to raise their intake of national employees at the rate of $2 \%$ annually, starting from 2004' (Gulf Business 2008:78; UAE Ministry of Foreign Affairs 2010).
The insurance sector in the UAE has been identified and ringfenced as an economically significant sector. The raison $d$ être for targeting the insurance sector for nationalisation is based on the following:

- It is attractive to the local Emirati population, as most of the jobs within the sector are not deemed to be peripheral or menial jobs.

- Its potential to rapidly facilitate economic diversification activities and the significance of the sector's contribution to the UAE's GDP.

- The potential to absorb the unemployed segment of the Emirati population. The Emirati work force in the insurance industry, according to Minister of Economy, '... represents a mere $8.9 \%$ or 768 of the 8590 workers in the industry'. (Salama 2014).

At the promulgation of the policy '...the Council of Ministers issued resolution No. 202/2 for 2003 obligating all insurance firms operating in the UAE to raise their intake of national employees to $15 \%$ by the end of 2003 , at the rate of $5 \%$ per year. Subsequently in 2005, the cabinet issued resolution No. 42 entrusting TANMIA with the task of monitoring the Emiratization of this sector' (UAE Ministry of Foreign Affairs 2010). According to Article 3 of said resolution, '...firms insurance companies shall provide TANMIA with updated data on their status of employment, Nationals' recruitment records (name, recruitment date, grade, etc.) and any other information that TANMIA may require'. (Ministerial Resolution 202/2: 2003). It is worth noting that the government is equally promoting and encouraging the recruitment of citizens with disabilities. Rule No. 275 for Disabled Emirati states that hiring a disabled Emirati national counts as hiring two Emiratis with no disability (Metcalfe \& Mimouni 2011:123). Ministerial Resolutions 442 and 443 for 2006 'localised all secretarial and human resources occupations' (Metcalfe \& Mimouni 2011:123). In 2007, the UAE's Ministry of Labour '...clustered the hospitality, construction, and other service sectors not targeted before; to become incorporated into the Emiratisation programme' (Dubai Economic Council 2011:74).

\section{Systemic barriers and challenges}

Emiratisation is of the highest priority on the UAE government's agenda. The challenge of replacing expatriates with nationals, particularly in the private sector, remains intractable for the unemployed and difficult for future school leavers and graduate cohorts from the colleges and universities (Al-Ali 2008:56). Both government and the private sector have contributed to the systemic problems encountered in implementing the Emiratisation policies. The epistemological realities of the Emiratisation project are discussed and contextualised below.

\section{Embedded rentierism}

The concept of rentierism and the rentier state in the Middle East owes its genesis to Mahdavy (1970), who developed the rentier state approach to analyse the role played by oil rents 
in Iran. Rentierism has produced what is called a 'rentier society', in which citizens are said to have an income without sometimes working. So a kind of 'rentier mentality' may be expected to prevail in such a society (Ayubi 1996:227). Middle East scholars such as Althani (2012), Beblawi (1987) and Ross (2001) have collectively narrated that since '...the discovery of oil across the region a "rentier class" has developed which generates an income through the collection of "rents." This includes providing agencies for foreign companies that wish to operate in the Arabian Gulf states, sponsoring foreign worker's permits in return for fees and real estate ownership and speculation'.

Almezaini (2010:3) and Aartun (2002:8) have espoused the view that the UAE characterises a rentier state which continues to shape the current structure of government. In return for loyalty and for not demanding political reform, the state offers its citizens enormous material wealth. Rentierism continues to enhance the legitimacy of the authorities'. The political economy of oil rentierism in the UAE creates a system and culture of dependency in which citizens become sociologically fixated on state patronage. Against that background Davidson (2008:177-178) believes that the 'rentier structures continue to tie the hands of the government to the burdensome distributive practices and breed a certain unproductive mentality among the indigenous or local population'. High oil prices have allowed the national and local governments to maintain a system of distributed wealth in which the citizens (only Emiratis), even the recently urbanised Bedouins, are provided with social welfare.

The federal government's Emiratisation policies have been hamstrung by socio-economic and political structures that 'maintain an extensive cradle to grave welfare system for the citizens of the UAE, which comprises numerous subsidies, grants, interest-free loans, free public services' (EIU 2011:45). In addition, both federal and local governments provide attractively high salaries and guaranteed employment in the public sector for their citizens. It was not surprising then when Olarte-ulherr (2013) noted that 'none of the three sectors have met the targeted quotas stipulated in the labour nationalisation policies'. The failure by private sector firms to comply with the law, decrees and ministerial resolutions (as outlined above) is due in part to the UAE's traditional patrimonial structure. Al-Kitbi (2009:71) explains that '...the GCC including the UAE are still in the "patron state" phase and have not reached that of a "partnership state." The relationship between the state (UAE) and its citizens is still based on the fact that the subjects are not partners'.

By maintaining rentier structures in the society, and notwithstanding the inducements for Emiratis to join the private sector, there is still unwillingness by many locals to seek employment in the private sector. Thus, the government's contradictory policies have been hampering the success of Emiratisation policies in terms of the prescribed numerical targets. Essentially, the UAE's rentier arrangements have played a significant 'role in shaping negative attitudes toward employment in the private sector and in some cases employment in general. The local population has become heavily dependent on the state, hence they have lost the urge or the need to exploit their full potential' (Kayed \& Hassan 2011:61). Rentier policies as practised in support of political legitimacy are in direct opposition to labour market localisation policies.

\section{Perception and coloniality}

Emiratisation as a public policy is secured by decrees and regulatory safeguards. In spite of this, there is a pervasive allo-cultural or ethnocentric view of Emiratis and their attitude towards work. Middle East scholars Abdulla (2010) and Malit and Al Youha (2013) have remarked that:

...UAE nationals are perceived or stereotyped as incompetent, lazy, and dependent, they have no need for meaningful employment, a poor work ethic, and poor educational achievement, which negatively shapes their value within the labour market. Employers generally prefer high-skilled expatriates and often ignore the presence of high-skilled UAE nationals, giving rise to economic competition between the twoand leaving Emirati professionals generally underutilized within the labour market.

This is not dissimilar to the empirical findings of Al-Waqfi and Forstenlechner, which revealed the general belief that Emiratis are negatively stereotyped by expatriates in the UAE labour market' (2010:iii). The Arab work ethic is explained to be in direct opposition to the Protestant work ethic, which regards work as a noble act, developing the character and capabilities of people (Albayrakoglu 2010:40). These negative perceptions are also reinforced by a segment of the Emirati population that has a tendency to use the religious expression inshallah, meaning 'God willing' (to indicate the pace at which a task will be performed and or when a decision will be made on a matter). This is often construed by Westerners as a lack of competence in the individuals who are tasked with the responsibility to serve the public.

The process of Emiratisation and its effectiveness are undermined by a matrix of negative perceptions and unequal power relations that is disproportionately concentrated in the hands of a transient and residential capitalist class. The UAE Yearbook (2010:156) states that '...the private sector provides the majority of jobs in the UAE, accounting for nearly $63.3 \%$ of the total workforce in 2008 '. Statistically and stylistically, these figures highlight the asymmetrical power relations that presently exist between the private sector businesses and the state. Thus, it is not surprising that '... there have been emotive claims that the affirmative action project has been transmuted into special acquisitive rights, preferential treatment and privileges' (Dupper \& Sankaran 2014:143).

Emiratisation has also been hampered by the maintenance and manifestation of a colonial modality of thinking in a labour market that is based on racial social hierarchy. Quijano 
(2000:3) enunciates that such social arrangements are based on 'the concept that humanity is differentiated into inferior and superior, primitive and civilised'. Such views are manifested in the social stereotypes about the Emirati citizenry's work ethic or lack thereof. Maldonado-Torres reminds us that 'coloniality survives colonialism. It is maintained alive in books, in the criteria for academic performance, in cultural patterns, in common sense, in the self-image of peoples, in aspirations of self, and so many other aspects of our modern experience' (2007:243). Essentially coloniality and negative racial stereotypes are constitutively two sides of the same coin in the UAE. Thus, provided that Emiratis are still placed within a racial/ethnic peripheral zone, government labour localisation policies will continue to remain a systemic barrier in the private sector.

\section{Mudir syndrome}

The concept of the mudir ('boss') syndrome was coined and popularised by Daryl Champion in an attempt to explain the power relations and attitudes of Saudi Arabians toward jobs in the lower spectrum of the Saudi Arabian labour market. The mudir syndrome concept is defined as 'honour in employment which dictates that nothing less than a position of authority, status and respect is acceptable' (Champion 1998 cited in Henry \& Springborg 2001:181). This definition is inscribed in the sociology of businesses by a significant percentage of private sector entities owned by both locals and expatriates who are generally unwilling to hire Emiratis owing to the mudir syndrome mentality. This mentality emanates out of cultural and what Budhwar and Mellahi regard as the '...social values that have inscribed big egos and immense sense of pride of the Arabian people' (2006:132). This syndrome poses a significant challenge and hindrance in the UAE for policymakers in relation to Emiratisation as a social and economic empowerment policy. This situation is further exacerbated by the UAE's semi-neoliberal migration policies that '....allow temporary workers to carry out tasks that local Emiratis will not and do not wish to perform' (Tardif 2011:84). Quintessentially, the labour market segmentation theory encapsulates the attitude and disdain that nationals have towards an occupational group of jobs (menial, dirty, status-less) that fall on the lower echelon of the UAE segmented labour market.

Scholars such as Rees et al. (2007) and Raven (2011) and Randeree (2012) who have analysed the UAE Emiratisation project have articulated that 'a distinguishing feature of the UAE segmented labour market is that Emiratis view jobs or occupational groups on the lower end of the labour market as beneath them to perform'. Thus, they (Emiratis) do not avail themselves of the so-called peripheral and menial jobs. Instead the educated class of the citizenry seeks to dominate or create a monopolistic block as labour supplier in the upper echelons of private sector businesses. The interlocking of the mudir syndrome and labour market segmentation theory explains the reason why:

...vast majority of foreign-born working men are employed in low-skilled service sectors, while women are most often employed in domestic services and retail jobs. The region also attracts large numbers of high-skilled migrants from countries of the Organization for Economic Cooperation and Development, particularly in the oil and gas, education, finance, and investment sectors. (Malit \& Al Youha 2013)

The effectiveness of the UAE's labour nationalisation policies is being undermined by a scenario in which the private sector is unable to compete with the public sector remuneration packages. The mudir syndrome has also contributed to 'the low number of Emiratis working in the private sector because the salaries and benefits were not as good as they are for government workers' (Arabianbusiness. com 2014). A new labour law being promulgated by the UAE Ministry of Labour seeks 'to guarantee the same salaries and benefits of those working in governmentrelated jobs in the public sector' (ibid. 2014). At a political level the proposed new legislation aims firstly to legislate away a deeply embedded psychological mindset and secondly to achieve the intended objectives of Emiratisation policies. The hope is that in the process, a new political economy in the labour market will be created. At the epicentre of the mudir syndrome is a tacit attempt to institutionalise in the private sector a culture and mentality of self entitlement which is prevalent in the UAE's public sector. Systemically, this syndrome, especially in a minority state such as the UAE where there is a bidding war for talent, prevents private sector businesses from complying with the Emiratisation policies.

\section{Conclusion}

This article dealt with the shifts in the population demographics that have occurred due to the rapid pace at which petro-dollars were used to transform the UAE's economy. These shifts have culminated in a demographic imbalance where expatriates far outnumber the local Emirati population. Consequently, the ethnicisation and peripherisation of the Emiratis have forced the government to use social policies to address both the peripherisation of the local population and also the demographic imbalance. There are challenges and constraints that have prevented the projected success of the quota-designed process, as '...many private sector firms are not willing to employ, train unskilled and inexperienced nationals and then pay them considerably more than the rates paid to foreign workers' (Wilkins 2001:156).

The discussion in the body of the article highlights the fact that the issues of Emiratisation are complicated and cannot be solved based on the use of employment quotas in the banking, trading and insurance sectors. Forstenlechner and Rutledge (2012) noted that for a '...change the political economy discourse on the Arabian Gulf state will not be focused on its geostrategic importance, but instead on the demographic pyramid profile and the idiosyncrasies of its labour market'. The social order in the private sector hinges on an axis that owes its historical roots to the plantation 
economy, in which unequal power relations are embedded in the designs of a global capitalist system. Therefore, Emiratisation policies, as discussed earlier in the article, are aiming to reshape the political economy and segmented labour market of the UAE.

\section{Acknowledgements}

We also would like to acknowledge the kind assistance rendered to us by the librarians at the Dubai Statistics Centre and the Dubai Chamber of Commerce.

\section{Competing interests}

The authors declare that they have no financial or personal relationships that may have inappropriately influenced them in writing this article.

\section{Authors' contributions}

P.T. has contributed the subsequent sections of the article. H.W. contributed the first three sections of the article.

\section{References}

Aartun, A.L., 2002, 'The political economy of the United Arab Emirates: An analysis of the UAE as an oil rentier state', Unpublished thesis, University of Oslo, Oslo.

Abdulla, F., 2010, Stereotypes can stymie the UAE's development, viewed 12 July 2013, from http://www.thenational.ae/news/stereotypes-can-stymie-the-uaesdevelopment

Al Abed, I., Vine, P. \& al-Jabali, A. (eds.), 1996, Chronicle of progress: 25 tears development in the United Arab Emirates, Trident Press, London.

Al-Ali, J., 2008, 'Structural barriers to Emiratisation: Analysis and policy recommendations', Unpublished MA thesis, Victoria University, Australia.

Al-Awadh, A., 2007, United Arabic Emirates demographic change and the social factor, viewed 12 September 2014, from http://www.ecssr.ac.ae/ECSSR/print/ $\mathrm{ft}$.jsp?lang=en\&ftld=/FeatureTopic/Abdullah_AlAwadhi/FeatureTopic 0960.xml

Albayrakoglu, E.P., 2010, 'Global economic factors on Gulf labour dynamics: Localisation versus immigration', International Journal of Economics and Finance Studies 2(2), 39-45.

Al-Kitbi, I., 2009, Citizenship in Gulf countries, ESSR Publications, Abu Dhabi.

Almezaini, K., 2010, Private sector actors in the UAE and their role in the process of economic and political reform, viewed 27 May 2011, from http://arab-reform.net/ IMG/pdf/Private_Sector_Actors_in_the_UAE.pdf

Althani, M., 2012, The Arab Spring and the Gulf States: Time to embrace change, Profile Books, London.

Al-Waqfi, M. \& Forstenlechner, I., 2010, 'Stereotyping of citizens in an expatriatedominated labour market: Implications for workforce localization policy', Employee Relations 32(4), 364-381. http://dx.doi.org/10.1108/0142545101 Employee
1051596

Alzaabi, A., 2012, 'The risks that foreign labour poses to UAE national security', Unpublished BA thesis, Zayed Military College, Abu Dhabi.

Arabianbusiness.com, 2014, Emiratis in private sector jobs to get public sector salaries, benefits, viewed 12 August 2013, from http://www.arabianbusiness. com/emiratis-in-private-sector-jobs-get-public-sector-salaries-benefits-573132. html

Ayubi, N.N., 1996, Over-stating the Arab state: Politics and society in the Middle East, I.B. Tarius \& Co, London.

Bauder, H., 2001, 'Culture in the labor market: Segmentation theory and perspectives of place', Progress in Human Geography 25(1), 37-52. http://dx.doi. org/10.1191/030913201672119762

Beblawi, H. (ed.), 1987, The rentier state, Croom Helm Publishers, New York.

Birks, J.S. \& Sinclair, C.A., 1980, Arab manpower: The crisis of development, Croom Helm, London.

Bourdieu, P., 1984, Distinction: A social critique of the judgment of taste, Routledge, London.

Budhwar, P.S. \& Mellahi, K. (eds.), 2006, Managing human resources in the Middle East, Routledge, New York.

Davidson, C., 2005, The United Arab Emirates: A study in survival, Tynne Rienne Publishers, Inc., Boulder, CO.

Davidson, C., 2008, Dubai: The vulnerability of success, Columbia University Press, New York.
Dubai Economic Council, 2011, Business environment, enterprise performance and the development in Dubai, Dubai Economic Council, Dubai.

Dupper, O. \& Sankaran, K. (eds.), 2014, Affirmative action: A view from the global south, SunMedia, Stellenbosch.

Ehrenberg, R.G. \& Smith, R.S., 1997, Modern labour economics: Theory and public policy, 6th edn., Addison-Wesley, Reading, MA

EIU, 2011, Spring tide: Will the Arab risings yield democracy, dictatorship or disorder? EIU, London.

El-Sanabary, N., 1992, Education in the Arab Gulf States and the Arab World: Annotated bibliographic guide, Garland Publishing, New York.

Forstenlechner, I. \& Rutledge, E.J., 2012, 'The GCC's "demographic imbalance": Perceptions, realities and policy options', The Middle East Policy Council, viewed 18 July 2012, from http://www.mepc.org/journal/middle-east-policy-archives/ gccs-demographic-imbalance-perceptions-realities-and-policy-options?print

Gamburd, M.R., 2010, Sri Lankan migration to the Gulf: Female breadwinners Domestic workers in migration and the Gulf. Middle East Institute 2 Viewpoints, viewed 22 October 2013 from http://www.mei.edu

Girgis, M., 2002, The GCC factor in the future Arab migration. Submitted to Fourth Mediterranean Development Forum Amman, viewed 24 July 2012, from http:// www.mafhoum.com/press4/117S22.pdf

Global Compact International Yearbook, 2009, The global compact in the United Arab Emirates, Muenster: United Nations Publications.

Goodwin, S.M., 2006, 'Globalization, education \& Emiratization: A study of the United Arab Emirates', The Electronic Journal of Information Systems in Developing Countries 27(1), 1-14.

Grosfoguel, R., 2009, 'A decolonial approach to political-economy: Transmodernity, border thinking and global coloniality', viewed 25 June 2013, from http://www. postkolonial.dk/artikler/kult_6/GROSFOGUEL.pdf

Gulf Business, 2008, Home grown talent, Motivate Publishing, Dubai.

Henry, C.M. \& Springborg, R., 2001, Globalization and the politics of development in the Middle East, Cambridge University Press, Cambridge.

Hertog, S., 2010, 'Defying the resource curse: Explaining successful state owned enterprises in rentier states', World Politics 62(2), 26-301. http://dx.doi. org $/ 10.1017 /$ S0043887110000055

Hudson, M., 2009, The incremental approach to political reform in the Gulf in the ECSSR. The Arabian Gulf: Between conservatism and change, ECSSR, Abu Dhabi.

Kanna, A. 2010. FLEXIBLE CITIZENSHIP IN DUBAI: Neoliberal Subjectivity in the Emerging "City-Corporation". Cultural Anthropology, 25: 100-129. http://dx. doi.10.1111/j.1548-1360.2009.01053.x

Kapoor, D.C., 2002, Export management, Vikas Publishing House, New Delhi.

Kawach, N., 2010, National jobless rate peaks at 14\% in 2009, viewed 14 July 2012 from http://www.emirates247.com/news/emirates/national-jobless-rate-peaksat-14-in-2009-2010-08-12-1.278241

Kayed, R.N. \& Hassan, M.K., 2011, 'Saudi Arabia's economic development: Entrepreneurship as a strategy', International Journal of Islamic and Middle Eastern Finance and Management 4(1), 52-73. http://dx.doi.org/10.1108/ Eastern Finance and

Khondker, H.H., 2008, Social change in the United Arab Emirates: Challenges of migration and 'Emiratisation', Middle East Institute, Singapore, viewed 9 November 2015, from http://www.mei.nus.edu.sg

Koji, H., 2011, 'Controversies over labour naturalization policy and its dilemmas: 40 years of Emiratisation in the United Arab Emirates', Kyoto Bulletin of Islamic Area Studies 4(1 \& 2), 41-61.

Kothari, C.R., 2006, Research methodology techniques, Dharmesh Printers, Delphi.

MacQueen, B., 2013, An introduction to Middle East politics, SAGE Publications, London.

Mahdavy, H., 1970, 'The pattern and problems of economic development in rentier states: The case of Iran', in M.A. Cook (ed.), Studies in the economic history of the Middle East, pp. 428-467, Oxford University Press, New York.

Maldonado-Torres, N., 2007, 'On the coloniality of being: Contributions to the development of a concept', Cultural Studies 21(2-3), 240-270. http://dx.doi. org/10.1080/09502380601162548

Malit, F.T. \& Al Youha, A., 2013, 'Labor migration in the United Arab Emirates: Challenges and responses', viewed 22 April 2015, from http://www. migrationpolicy.org/article/labor-migration-united-arab-emirates-challengesmigrationpolicy
and-responses

Mashood, N.S., Verhoeven, H. \& Chansarkar, B., 2009, Emiratisation, Omanisation and Saudisation- common causes: Common solutions?, viewed 09 July 2012, from http://wbiconpro.com/17.\%20Helen-UAE.pdf

Mattar, K., 2009, Attempts to end the dependency on migrant labour in the Gulf region in the Arabian Gulf: Between conservatism and change, Emirates Centre for Strategic Studies and Research, Abu Dhabi.

Matthiesen, T., 2015, 'Centre-periphery relations and the emergence of a public sphere in Saudi Arabia: The municipal elections in the Eastern Province, 1954-1960, British Journal of Middle Eastern Studies 42(3), 320-338. http://dx.doi.org/10.1080/ 13530194.2014.947242

Metcalfe, B. \& Mimouni, F. (eds.), 2011, Leadership development in the Middle East. Edward Elgar Publishing, Cheltenham.

Mignolo, W., 2000, Local histories/global designs: Coloniality, subaltern, knowledges and broader thinking, Princeton University Press, Princeton, NJ. 
Ministry of Foreign Trade, 2010, Trade policy review United Arab Emirates, Department of Foreign Trade Policies: Abu Dhabi.

Modarress, B., Ansari, A. \& Lockwood, D., 2013, 'Emiratization: From policy to implementation', International Journal of Human Resources Development and Management 13(2), 188-205. http://dx.doi.org/10.1504/IJHRDM.2013. 055395

Mosedale, J., 2011, Political economy and tourism: A critical perspective, Routledge Publications, New York.

Ndlovu-Gatsheni, S.J., 2013, Coloniality of power in postcolonial Africa. Myths of decolonization, African Books Collective, Oxford.

Olarte-ulherr, O., 2015, 'No sector has met \& Emiratisation target', Khaleej Times, February 6, viewed 16 March 2016, from, http://www.khaleejtimes.com/nation/ general/no-sector-has-met-emiratisation-target

Pacione, M., 2005, 'City profile Dubai', Cities 22(3), 255-265. http://dx.doi org/10.1016/j.cities.2005.02.001

Quijano, A, 2000, 'The coloniality of power and social classification', Journal of WorldSystems Research 6(2), 342-386.

Ramos, S.J., 2008, Sinews of growth: Generative infrastructural urbanism in Dubai. Policy Brief No.4 (May).Dubai School of Government, Dubai.

Randeree, K., 2012, Workforce nationalization in the Gulf Cooperation Council States. Occasional Paper No. 9, Center for International and Regional Studies Georgetown University School of Foreign Service, Qatar.

Raven, J., 2011, 'Emiratizing the education sector in the UAE: Contextualization and challenges', Education, Business and Society: Contemporary Middle Eastern Issues $4(2), 134-141$.
Rees, C.J., Mamman, A. \& Braik, A.B., 2007, 'Emiratization as a strategic HRM change initiative: Case study evidence from a UAE petroleum company', International Journal of Human Resource Management 18(1), 33-53.

Reich, M., Gordon, D. \& Edwards, R.C., 1973, 'Dual labor markets: A theory of labor market segmentation', American Economic Review 63(2), 359-365.

Ross, M., 2001, 'Does oil hinder democracy?' World Politics 53, 325-361.

Salama, S., 2014, UAE targets 15\% Emiratisation in insurance by 2015 , minister says, viewed 11 September 2014, from http://gulfnews.com/news/gulf/uae/ government/uae-targets-15-emiratisation-in-insurance-by-2015-ministersays-1.1351682

Shihab, M., 2001, 'Economic development in the UAE', in I. Al-Abed \& P. Hellyer (eds.), United Arab Emirates: A new perspective,pp. 249-259, Trident Press Limited London.

Sorenson, D.S., (edn.), 2010, Interpreting the Middle East, Westview Press, Boulder, CO.

Tardif, E, 2011, 'Culture socks in a globalized world: How "accommodating" do states need to be regarding the use of religious symbols in the public sphere?' need to be regarding the use of religious symbols in the public sphere?', IJPLAP.2011.041891

UAE, 2010, United Arab Emirates Yearbook, Trident Press, London.

UAE, 2013, United Arab Emirates Yearbook, Trident Press, London.

UAE, 2014, United Arab Emirates Yearbook, Trident Press, London.

Wilkins, S., 2001, 'International briefing 9 Training and development in the United Arab Emirates', International Journal of Training and Development 5, 153-165. http://dx.doi.org/10.1111/1468-2419.00129 